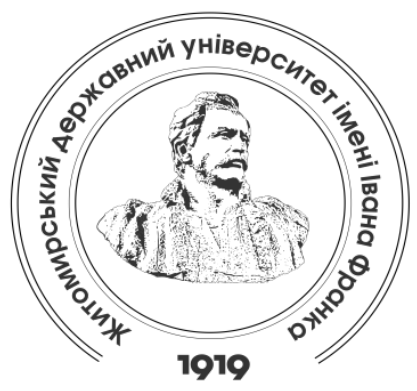

Zhytomyr Ivan Franko State University Journal. Philological Sciences. Vol. 2 (95)

Вісник Житомирського державного університету імені Івана Франка. Фімологічні науки. Вип. 2 (95)

ISSN (Print): 2663-7642

ISSN (Online): 2707-4463

\title{
УдК: 81-11
}

DOI 10.35433/philology.2 (95).2021.130-150

\section{ДОСАІДЖЕННЯ ОБРАЗНОГО ПОРІВНЯННЯ В ПЕРІОД ВІДРОДЖЕННЯ (16-18 СТОАІТТЯ)}

\section{М. Я. Оменяк ${ }^{*}$}

Стаття присвячена дослідженню кониепиій образного порівняння в епоху відродження протягом 16-18 століть як західної, так і східної традииій. У ній актуалізовано перехід від класичних фундаментальних напраиювань до ренесансного їх переосмислення в європейській спеціалізованій літературі, оригінальні тексти якої стали предметом аналізу. Установлено кореляиію термінології різних епох та окреслено залежність наукової думки від історичного етапу розвитку суспільства. З'ясовано, що через те, шо образне порівняння розглядалося як риторична фрігура, заиікавленість ним була обмеженою конкретними практичними завданнями, пов'язаними із мистеитвом красномовства й меншою мірою художнім стилем. Виокремлено функиії описуваної категорії, які виділяли провідні мовознавиі, а також визначено найбільш впливових дослідників, котрі поглибили розвиток основоположних приниипів потрактування образного порівняння класиками-риторами. У статті доведено, шо зміст, обсяг та ієрархія термінів на позначення образного порівняння різняться залежно від епох $i$ від авторів риторик, відображаючи нюанси перекладу давньогрецьких $і$ латинських текстів, розвиток лінгвістичної думки та поглиблення аналізу закладених давніми греками й римлянами напрямків дослідження. Установлено, що тільки наприкіниі 18-го століття введено до обігу англомовну актуальну досі термінологізовану лексему на позначення образного порівняння "simile" як нащадок низки багатозначних, не завжди спеиіалізованих термінів (homoeosis, icon, paradigma, parabola, similitude, resemblance, comparison), нерідко синонімічних між собою.

Ключові слова: образне порівняння, метафора, компаративність, Відродження, риторика, mpon, фігура мовлення.

\section{RENAISSANCE RESEARCH ON SIMILE (16TH-18TH CENTURIES). Oleniak M. Ya.}

The article deals with the study of the concepts of simile in the Renaissance during the $16^{\text {th }}-18^{\text {th }}$ centuries in both Western and Eastern traditions. It outlines the transition from the classical

\footnotetext{
* кандидат філологічних наук, доиент

(Донеиький національний університет імені Василя Стуса, м. Вінниия) maryana@mail.org

ORCID:0000-0002-5888-326X
} 
fundamentals to their renaissance interpretation in the European specialized literature, the original texts of which became the subject of analysis. The correlation of terminology of different epochs is established and the dependence of scientific thought on the historical stage of society development is highlighted. It was found that because simile was regarded as a rhetorical figure, interest in it was limited to specific practical tasks related to the art of eloquence and, to a lesser extent, belleslettres style. The functions of the described category, which were singled out by leading linguists, are stated as well as the most influential researchers who deepened the development of the basic principles of simile interpretation by classical rhetoricians. The article proves that the content, scope and hierarchy of terms for simile differ depending on the eras and the authors of rhetoric, reflecting the specifics of translation of ancient Greek and Latin texts, the development of linguistic thought and deepening the analysis of ancient Greeks and Romans. It is established that only at the end of the 18th century the English term "simile" was introduced as a descendant of a number of ambiguous, not always specialized terms (homoeosis, icon, paradigm, parabola, similitude, resemblance, comparison), often synonymous with one another.

Keywords: simile, metaphor, comparativeness, Renaissance, rhetoric, trope, figure of speech.

\section{Постановка \\ проблеми.}

Загальноприйнятою є думка про те, що коріння дослідження образного мовцення сягають глибокої давнини, однак у переважній більшості випадків, якщо мовознавці й звертаються до історичної спадщини мінгвістики в цьому аспекті, то, як правимо, обмежуються констатацією початку відповідних досліджень в епоху Античності, 3 подальшим викладом сучасних концепцій, повністю залишаючи поза увагою епохи Середньовіччя та Відродження, що й зумовлює актуальність статті.

Аналіз останніх досліджень $i$ публікацій. Сучасні теорії метафори, а відтак i образного порівняння, яке практично завжди розглядають у світлі теорії метафори, переважно позиціонуються як такі, що стоять в опозиції до класичних традицій, пов'язаних насамперед з Аристотелем, котрий розглядав метафору тілтки 3 позиції ії функціонування в мітературі та ораторських промовах [3: 22; 13: 190-193; 18: 3]. Однак із відносною долею впевненості можна стверджувати, що не тільки дослідження образності сягають епохи Античності, але й сучасна термінологія та окремі аспекти потрактування фігуративного мовлення несуть у собі відбитки становцення наукової думки протягом усіх історичних епох, які певною мірою визначали стан розвитку мінгвістики, котра згодом $\begin{array}{llr}\text { розвинулася } & 3 & \text { риторики. } \\ \text { Прихильниками } & \text { такого } & \text { бачення }\end{array}$

проблеми можна вважати багато дослідників $[10 ; 12 ; 15 ; 17 ; 21 ; 22 ; 25$; 26], які знаходять ремінісценції аристотелівських вчень у сучасних когнітивних теоріях метафори. Зокрема, Swiggers [25] вбачає "дивовижно сучасні" тенденції в потрактуванні метафоричних процесів Аристотелем, у яких він простежує мінгвістичні, когнітивні та культурні параметри аналізу. Kirby [12: 518] вважає, що дещо поблажливе, а інкоми й агресивне, ставлення до теорій Стагирита $€$ питанням моди й користанням із того, що подальша полемізація з ним неможлива. Про некоректне тлумачення та перебільшення різниці в поглядах на метафору давньогрецькими i сучасними дослідниками пише Filonik [10], який стверджує, що когнітивні аспекти метафори були досить чітко сформульовані в давньогрецьких теоретичних працях і що Аристотель розглядав метафору не тільки як риторичний прийом, ase i як концептуальний процес, що згодом частково було втрачено в давньоримській риториці, яка слугувала основою пізніших європейських студій. Novokhatko, вивчаючи мінгвістичне потрактування метафори Квінтиліаном, робить висновок, що "незважаючи на те, що Квінтиліан термінологічно залишається 
в царині риторики, він достатньо прогресивно висвітлює деякі аспекти когнітивного, семантичного та прагматичного потрактування метафори, що наближається до того, що $\Lambda$ акофф назвав би “головним механізмом, за допомогою якого ми розуміємо абстрактні поняття та виконуємо абстрактні міркування" [17: 317].

Метою статті $є$ заповнення макуни в історіографії дослідження образного порівняння в період з 16 по 18 століття шляхом аналізу тогочасних європейських риторик, з'ясування їх впливу на подальше потрактування цього явища та опис особливостей розвитку термінів на його позначення.

Викмад основного матеріалу
дослідження 3 обтрунтуванням
отриманих наукових резумьтатів.
Становцення мовознавства в період Відродження втілюється передовсім у пристрасному зацікавленні й перекладах античних авторів та написанні граматик багатьох європейських мов. Ці два напрямки засвідчують певну єдність процесів розвитку національних мітературних мов як повноправних із матиною способів комунікації та питань, пов'язаних із іx вивченням. Прописуються "механізми" устрою описуваних мов, які пов'язуються 3 могікою, риторикою та метафізикою в дусі традиціоналізму, що панував ще 3 часів античності.

Бмизько 1530 року Аеонард Кокс публікує працю The Arte or Crafte of Rhethoryke" "Мистецтво або ремесла риторики", яку вважають першим підручником із риторики, написаним англійською мовою, де він не оперує середньовічними термінами homoeosis, icon, paradigma чи parabola, уживаючи натомість узагальнений термін comparison 'порівняння' [7: C.iiii.r] та pleasaunt figures 'приємні фігури' [7: B.i.r], які використовує вмілий ритор у процесі ведення дискусії. Проте цікавим у плані переосмислення використовуваних термінів $є$ переклад першого тому парафразу Еразма Роттердамського Нового завіту Ніколасом Удамлом, який побачив світ у 1548 році. У ньому всі образні оповіді Христа, які Еразм услід за середньовічними теологами позначає терміном parabola 'придумане порівняння', іменуються similitude 'подібність' [9], що, з одного боку, свідчить про тогочасну термінологічну невизначеність, а 3 іншого - про сумнівність із позиції перекладача доцільності виокремлення терміна на позначення зіставлення живого i неживого об'єкта.

Приблизно через 20 років після Кокса Річард Шеррі створює Treatise of Schemes and Tropes "Трактат про схеми i тропи", у якому інтерпретує образне порівняння саме в термінах фігур Середньовіччя (icon, parabola, paradigma), щоправда, не згадуючи гіперонімний термін homoeosis. Шеррі визнає джерела формування своїх поглядів (Цицерон, Квінтиліан, Еразм), проте претендує на новизну потрактування фігур мовлення: "I haue not translated them orderly out of anye one author, but runninge as I sayde thorowe many, and vsyng myne owne iudgement, haue broughte them into this body as you se, and set them in so playne an order, that redelye maye be founde the figure, and the vse wherevnto it serueth" ("Я не робив перекладу котрогось 3 авторів, натомість, як я вже говорив, вивчив багатьох, i, керуючись власним баченням, створив запропоновану вам класифікацію, викладену в зручному порядку, який дозволяє швидко віднайти фігуру 3 прикладами її використання") [23: 11]. Він справді системно й послідовно подає матеріал, а також уперше робить спробу проаналізувати описані фігури 3 позиції суміжності й термінологічної неоднозначності. Як приклад різновиду образного порівняння, позначуваного терміном parable, автор наводить зіставлення корабля 3 піднятими чи опущеними вітрилами (залежно від наявності вітру) та здатність 
підиаштовуватися під ситуацію: "...а shyp in the whych the sayles be hoysed vp, or takẽ down after the blowyng of the winde, is a parable whiche teacheth a wyse man to geue place to tyme, and applye hymselfe to the world that is presente" ("...корабель, в якого вітрица підняті, або після поривів вітру опущені, є прикладом parable, який вчить розумну мюдину виждати потрібний момент і призвичаїтися до поточної ситуації") [23: 91]. Натомість, демонструючи різновид образного порівняння, іменованого icon, зістав яється Аюдина з твариною: "...a man flewe vpon his enemies like a dragon, or lyke a lyon" ("...чоловік кинувся на своїх ворогів як дракон або як мев") [23: 92], що також можливо у випадку різновиду образного порівняння, названого similitude: "As an Asse wyll not be driuen from her meat, no not with a club, vntyl she be full: no more wil a warriour reste from murther vntyll he hath fylled his mynd with it" ("Як віслюка неможливо відтягнути від їжі, навіть палкою, поки він не наїсться, так само і воїн не може не думати про вбивство допоки не задовільнить своє бажання") [23: 92]. Шеррі стверджує, що інколи parable називають similitude 'подібність', а інколи cõparacion 'порівняння', зазначаючи повчальний характер описуваного явища як окремого прийому, який зіставляє неживі об'єкти з живими на основі аналогії. Він також констатує, що icon 'образ' $є$ дуже подібним до similitude 'подібності' й за певних обставин може 3 нею ототожнюватися; крім того, автор визнає наявність могічної операції comparacion 'порівняння' у випадку icon, що фактично прирівнює явища, позначувані термінами parable та icon як такі, що базуються на однаковому прийомі - порівнянні та актуалізують однакову ознаку - подібність. Шеррі стверджує, що автори не завжди розмежовують фрігури та тропи (проте сам не робить такої "помилки"), і традиційно зараховує до останніх метафору. Така педантична прихильність до розмежування тропів і фігур, очевидно, не дає йому змоги порівнювати образне порівняння (безвідносно до терміна, ужитого на його позначення) i метафору, хоча мінгвіст визнає, що остання також базується на similitude 'подібності' [23: 40]. Услід за попередниками Шеррі констатує сім типів переносу значення в метафорі (істота - істота; істота неістота i т.д.). Отже, принциповий розподіл образних утворень на фігури й тропи продовжує провокувати певний термінологічний плеоназм у випадку образного порівняння, натомість щодо метафори аналогічні явища результують у формі внутрішньої класифікації типів зіставлюваних доменів.

Приблизно в цей самий час над своєю версією підручника 3 риторики працює Томас Уілсон, який уперше виходить друком у 1553 році під назвою "The Arte of Rhetorique" ("Мистецтво риторики"). Новизна Уіцсона полягає в зменшенні кіцькості різновидів образного порівняння (очевидно, методологійною базою для Уілсона слугували роботи Квінтиліана та ad Herenium, де фрігурують мише терміни similitudo та imago), а також у переосмисленні тропів і фрігур, які він упорядковує в гіпонімно-гіперонімні відношення. Іншими словами, у риториці Уілсона й метафора, й образне порівняння вважаються тропами, 3 тією мише різницею, що метафора належить до "tropes of a worde" 'тропів слова', а образне порівняння, позначене терміном similitude 'подібність' - до "tropes of a long continuous speeche or sentences" 'тропів довгого тривалого мовлення або речення' [27: 172]. Як методичної рекомендації до використання тропу similitude 'подібність' Уілсон звертає особливу увагу на важливість фонових знань про еталон порівняння: "Therefore, those that delite to proue thinges by Similitudes, must learne to knowe the nature of diuers beastes, of 
mettalles, of stones, and al such as haue any vertue in them, and be applied to mans life" ("Отже, ті, хто хочуть використовувати образні порівняння 3 метою аргументації, повинні знати природу різних тварин, металів, каміння а також цінність, яку вони представляють для використання в житті однак, автор подає resembling of things 'схожість об'єктів' як прямий відповідник матинському imago 'образ', яку він визначає "Resembling of thinges, is a comparing or liking of looke, with looke, shape, with shape, and one thing with an other" "Схожість предметів - це порівняння або уподібнення вигляду з виглядом, форми 3 формою, одного предмету 3 іншим' [27: 207]. I хоча сам Уілсон не надає критерії розмежування тропів "подібності" і "схожості об’єктів", із наданих визначень i наведених прикладів можна припустити, що перший троп актуалізує подібність за певною властивістю, тоді як другий за зовнішньою ознакою. Подібність також, стверджує автор, є основою дия метафори, хоча різниця між образним порівнянням і метафорою, крім констатації належності їх до різних видів тропів, не пояснюється.

1577 року з'являється черговий каталог риторичних тропів і фігур "The Garden of Eloquence" ("Сад красномовства"), укладений Генрі Пічемом [19]. Його вважають найповнішою англомовною риторикою епохи Відродження; утім, образне порівняння не знаходить там більш конкретизованого опису, ніж у працях його попередників. Навпаки, інформація подається досить стисло, 3 деякими прикладами, запозиченими в Річарда Шеррі. Пічем, очевидно наслідуючи моду тогочасної Британії, використовує матинізовану версію термінології (parabola замість на той час уже сформованої словоформи parable) i "переописує" класифікацію образного порівняння, яка базується на категоризації Беди Преподобного i Річарда Шеррі.

Наприкінці XVI століття у світ виходить робота Джорджа Путтенгама "The Arte of English Poesie" ("Мистецтво англійської поезії"), у котрій у коментарях до образного мовлення Чосера з'являється нове поєднання термінів similitudes comparisons 'порівняння подібності' [20: СНАР. $\mathrm{XXXI],} \mathrm{водночас} \mathrm{у} \mathrm{попередніх}$ підручниках із риторики ці два поняття завжди розмежовувалися. Щоправда, ця колокація $\epsilon$ радше оказіональною, тому що в подальшому викладі матеріалу вона відсутня, однак навіть одноразове іiі використання свідчить про те, що автор, а відповідно і його сучасники, усвідомлювали той факт, що умовою створення та інтерпретації тропа чи фрігури similitude 'подібність' є могічна операція порівняння. Апелюючи до давньогрецьких першоджерел, Путтенгам пропонує свою класифікацію образного порівняння, якою фактично спростовуе необхідність розмежування тропів similitude 'подібність' i resembling of things 'схожість об'єктів' Уілсоном: "Now because there are sundry sorts of them [similitudes], which also do worke after diuerse fashions in the hearers of conceits, I will set them foorth by a triple diuision, exempting the generall Similitude as their common Auncestour, and I will cal him by the name of Resemblance without any addition, from which I deriue three other sorts: and giue euery one his particular name, as Resemblance by Pourtrait or Imagery, which the Greeks call Icon, Resemblance morall or misticall, which they call Parabola, \& Resemblance by example, which they call Paradigma" ("Через те, що їх є багато видів [подібностей], які по-різному можуть сприйматися слухачами думки, я далі поділю їх на три групи, виокремивши загальну Подібність в якості їхнього спіцьного Предка, і я назву іï Схожістю без жодних означень, в межах якої 
знаходяться три інші види: $і$ я дам кожному з них окрему назву, як то Схожість за Зовнішністю або Образом, яку Греки називають Icon, Схожість моральна або символічна, яку вони називають Parabola i Схожість за прикладом, яку вони називають Paradigma") [20: CHAP. XIX]. За тогочасними правилами пунктуації 3 великої мітери писалися "важливі" іменники, тому, виходячи з відмінності правопису найменування першої групи, можна припустити, що "Схожість за Образом" бума важливішою дия виокремленої категорії з позиції автора, ніж дві інших. Далі Путтенгам детальніше описує суть кожної 3 підгруп, ілюструючи ï прикладами, зокрема для "Схожості за Образом" він наводить порівняння Іїї Величності [Єлизавета I] зі змією (наймудріша), мевом (найвідважніший) і ангелом (найкрасивіший): "Nature that seldome workes amisse, In womans brest by passing art: Hath lodged safe the Lyons hart, And stately fixt with all good grace, To Serpents head an Angels face" ("Природа, яка рідко помиляється, наділила жінку неабиякими здібностями: в ній серце мева, мудрість змії і обличчя ангела") [20: CHAP. XIX]. Очевидною $\epsilon$ дуже умовна відповідність наведеного прикладу зазначеній вище назві підгрупи, адже об'єкти зіставляються не мише за зовнішною ознакою, але й за внутрішніми, "невидимими" характеристиками. Сюди ж, зазначає автор, можна відносити порівняння неживих об'єктів за ознакою кольору чи фізичних властивостей. Отже, розмежування порівняння відповідно до критерію близькості/віддаленості зіставлюваних категорій, яке було прийнято в Середньовіччі й позначалося такими ж термінами, зазнало вкотре певного переосмислення. Коментуючи "Схожість моральну або символічну", Путтенгам констатує ії метафоричний характер й обмежує використання творами

морально-етичної спрямованості, на кшталт Євангелія чи казок Езопа, водночас "Схожість за прикладом", пише критик, зводиться до наведення низки історичних прикладів, які можна порівняти 3 певною ситуацією, схиляючи слухачів до вибору описуваної мінії поведінки. Безперечно позитивним моментом у праці Путтенгама, порівняно 3 його сучасниками, $\epsilon$ конкретизація потрактування виокремлених фігур, що полегшує процес інтерпретації поглядів автора. Однак, проаналізувавши сфрормульовані ним потрактування, басимо очевидний факт спроби вдосконалення категоризації образного порівняння (наприклад, об'єднання неаргументовано розмежованих Уілсоном категорій "подібність" i "схожість" та встановлення кореляції 3 термінами першоджерел); утім, своєрідність смислового наповнення нової термінології також не аргументується. Три виокремлені категорії, по суті, базуються на різних критеріях: смислова аналогія ("Схожість за Образом"), дидактичність ("Схожість моральна"), яка також передбачає аналогію смислів та каузативність ("Схожість за прикладом"). Путтенгам (як й інші дослідники епохи Середньовіччя та Відродження), даючи давньогрецькі відповідники своїм трьом видам схожості, фрактично наповнює античні терміни новим смислом, повністю ігноруючи формальні складники розглядуваного явища, які, хоч і побіжно, але все ж згадувалися в першоджерелах i слугували критерієм розмежування образного порівняння і метафори.

На початку XVIII століття низку риторик пишуть викладачі КиєвоМогилянської академії, щоправда, матиною. Одним із найвідоміших $\epsilon$ український науковець Феофан Прокопович, автор "De arte poёtica" i "De arte rhetorica", який читав там мекції протягом 1705-1709 років, котрі 
згодом були перекладені українською мовою. Безсумнівно, визнаючи авторитет класиків, Феофан Прокопович поміщує образне порівняння в категорію фігур мовлення, констатуючи його повчальний характер, а також критично переосмислює й розвиває античні теорії. Автор радить використовувати цю фігуру, якщо виникає необхідність аргументації у "важливій справі" стосовно кількісних чи якісних показників. Як приклад науковець описує відвагу святого Василія, який заборонив безбожному імператорові увійти до церкви: "Цю всю картину бачив неначе намальовану на стіні, так безстрашно діяв все той муж". Переклад риторики Феофана Прокоповича засвідчує прецизійність автора у використанні термінології, яка віддзеркалює смислове наповнення первісних мексем: "образність", "вигадана подібність": "Якщо [йдеться] про кількість, дуже тонко можна подати іï за допомогою вигаданої подібності або порівняння" [2].

Ближче до середини XVIII століття

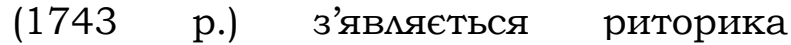
М. В. Аомоносова "Краткое руководство къ краснорпчію", написана під час кількамісячного ув'язнення, яка вирізняється своєрідністю в плані віддаленості від робіт авторитетних античних $\mathrm{i}$ тогочасних мислителів. Зокрема, образне порівняння автор не включає ні в перелік тропів, ні фігур, натомість поза іх межами згадується подобіe риторическое, яке за визначенням можна вважати будь-яким порівнянням, а за прикладами образним; воно також позиціонується як мета (а не основа) метафоричного перенесення. У тексті, в описах прикладів, які містять як образне, так і необразне порівняння, трапляється використання нетермінологізованих мексем подобіе, уравненіе, подобные вещи; як окремий складник подобіе відзначено в розділі про хрію - явище, суть якого досить важко зрозуміти i яке, за словами автора, не описане античними мислителями й часто вживається неправильно [1]. На відміну від усіх інших посібників із риторики, термінологія не подається в співвіднесенні 3 матинськими й грецькими назвами; крім того, відсутність образного порівняння як окремої фрігури не пояснюється. Отже, перша російська риторика має дуже обмежений вплив, якщо він узагалі $\epsilon$, на становцення історіографії в царині образного порівняння.

Iз середини XVIII століття в західноєвропейській $\quad$ мітературі спостерігається тенденція до започаткування вживання сучасного англомовного терміна на позначення образного порівняння - simile паралельно 3 (на той момент) традиційними similitude та parable в їніх різних орфографічних варіантах. Це, зокрема, характерно дмя Бмеквомла [4], чия праця "Introduction to the classics" ("Вступ до кцасики") вперше вийшла друком у1718 році; Гіббонса, автора "Rhetoric; Or, A View of Its Principal Tropes and Figures" ("Риторика; або, погляд на іï головні тропи i фігури"), у якій він, базуючись на теоретичному підгрунті римлян, наводить велику кількість прикладів образного порівняння 3 прозових i поетичних творів класиків i сучасників, однак сам аналіз нерідко робить відповідальністю читача [11].

У мекціях Адама Сміта, записаних двома його студентами (1762-1763) й у XX столітті опублікованих у книзі "Lectures on Rhetoric and Belles Lettres" ("Аекції 3 риторики та художнього стилю"), здійснено порівняльний аналіз тропів i фігур мовлення, де констатується, що образне порівняння $\epsilon$ близьким до метафори 3 позиції влучності підібраного еталону та доцікьності застосування [24: 30]. Його робота певною мірою може слугувати ймовірним поясненням усе частішого використання нового терміна simile. 
Річ у тому, що вживана із Середньовіччя лексема similitude (similitudo) 'подібність' почала розвивати додаткове значення 'прецедент' (на жаль, не зафіксоване етимологічними словниками), що дає підстави Сміту 3 гордістю новатора виокремлювати раніше не зареєстровану фігуру мовлення, іменовану Precedent 'прецедент' як підвид similitude: "This last [Precedent] which is so much in use amongst modern Lawyers was not at all used by the antients either Greeks or Romans ... they mention all the different sorts of Similitude except that of precedents ... therefore there is such a remarkable difference betwixt the modern and the ancient practise ..." ("Ця остання [фігура прецедент], яка так часто стає в нагоді сучасним юристам, зовсім не використовувалася ні греками, ні римлянами...вони згадують багато різних видів подібності (Similitude) окрім прецеденту...тому й існує така разюча різниця між сучасними i античними практиками...") [24: 174]. Установлення Смітом категорійних гіпонімо-гіперонімних відношень між "прецедентом" (Precedent) і “подібністю" (Similitude), з одного боку, стирає межу між могічним й образним порівнянням, які, відповідно, ними позначалися, а 3 іншого, можливо, саме через необхідність розмежувати в подальшому могічні й образні "подібності" паралельно 3 терміном Similitude починає функціонувати simile.

1776 року Джордж Кемпбем публікує працю "The Philosophy of Rhetoric" ("Філософрія риторикu"). Він зазначає, що образне порівняння (simile) $\epsilon$ втіленням власне порівняння (comparison), а метафора - алегорією в мініатюрі, яка $€$ нічим іншим ніж порівнянням, поданим у певній формі [6: 75], з чого можна висновкувати, що автор наближує образне порівняння до метафори. Як і в його сучасників, разом із терміном simile в роботі відзначено частково детермінологізовані мексеми similitude 'подібність' і resemblance 'схожість' як синоніми, ужиті на позначення будьякої аналогії, уподібнення чи прецедента, щоправда, similitude 'подібність' інколи використовується паралельно зі simile на позначення образного порівняння, яке, як стверджує автор, поєднує ознаки прямого та фрігуративного значення [6: 266]; функціонує як структура, що здатна оживити мовлення, візуалізуючи певну ментальну картину [6: 290]. Кемпбел також порушує питання перекладу образного мовцення, вважаючи, що образне порівняння відносно цегко можна перекласти іншою мовою без утрати ефекту, водночас метафору - ні.

1783 року З'являється авторитетна робота Х'ю Блера - курс мекцій, які він читав протягом двадцяти чотирьох років в Единбурзькому університеті й був вимушений надрукувати, щоб подати матеріал повністю та якісно викладеним, на противагу затребуваним і вже на той момент комерціалізованим конспектам його мекцій, зроблених студентами. На тлі розвідок його сучасників, образне порівняння в цій праці описано набагато грунтовніше, повніше й глибше. Автор послуговується тільки терміном simile 'образне порівняння' на позначення аналізованого явища, однак уживає мексему comparison 'порівняння' як абсолютний синонім і взагалі не називає в цьому значенні термін similitude 'подібність'. Відтак можна сказати, що на цьому етапі вже чітко простежується результат термінологізації simile i детермінологізації similitude. Блер, на відміну від його колег, чітко розмежковує метафору й образне порівняння не мише за формальним показником - наявністю маркера компаративності, але й за естетичною ознакою, силою відчуттів продуцента утворень: "...they [similes] are not, like the Figures of which I treated in the last Lec|ture, the language of strong passion. 
No; they are the language of imagination rather than of passion..." ("вони [образні порівняння] не такі, як фрігури пристрасної мови, про які я розповідав у попередній мекції [про метафору]... ") [5: 409]. Автор всебічно описує досліджувану категорію; і нехай він не заглиблюється в кожен з аспектів цього багатогранного явища, усе ж очевидним $€$ комплексний підхід до аналізу. Зокрема, Блер демонструє когнітивно-концептуальний підхід до потрактування образного порівняння, зазначаючи, що в ньому зіставляються поняття, котрі $€$ нічим іншим, ніж уявленням, ідеями які існують у свідомості автора й реципієнта виразів: "Two objects may sometimes be very happily compared to one another, though they resemble each other, strictly speaking, in nothing; only, because they agree in the effects which they produce upon the mind; because they raise a train of similar, or, what may be called, concordant ideas" ("Інкоми дуже вдамо можна порівняти два об'єкти, хоча вони, прямо кажучи, ні в чому не схожі; це можииво тільки тому, що вони узгоджено створюють ефект, який впливає на свідомість; тому що вони провокують манцюг подібних, або, інакше кажучи, відповідних ідей") [5: 408]. Крім того, мектор чи не вперше порушує питання історичної зумовленості й важливості національно-культурологічного аспекту образного порівняння, зазначаючи, що вибір еталона порівняння залежить від історичного періоду, у якому останнє використовується, і різниться в межах різних мінгвокультур. Не оминає стороною Блер і проблему сили ефекту цих конструкцій, пов'язану 3 категорійною віддаменістю зіставлюваних понять, констатуючи, що чим віддаленіші порівнюються поняття, тим сильнішим буде ефект від образного порівняння. Автор категоризує не тільки основні функції розглядуваної категорії (пояснювальну та декоративну), чим займалися майже всі їі дослідники, але й робить спробу класифікувати джерела виникнення образних порівнянь, яких виділяє три і які, за словами Блера, базуються на задоволенні: 1) від процесу пізнання (потрактовується як метод); 2) від можАивості чітко й конкретно описати предмет порівняння (тиумачиться як інструмент досягнення комунікативної мети); 3) від спроможності візуалізувати образ, апелюючи до уяви реципієнта (позиціонується як прийом, здатний стимулювати органи чуття мюдини). Він також озвучує правима використання образних порівнянь, які зводяться до аналізу контексту на предмет частотності використання, знайомості та зрозумілості еталона порівняння для слухача та доречності вживання залежно від інтенсивності емоцій автора.

Висновки й перспективи дослідження. Загалом потрактування образного порівняння в період із 16 по 18 століття характеризується насамперед глибокою повагою до античних напрацювань, які активно перекладають європейськими національними мовами 3 метою освіти громадян рідною мовою, хоча матина ще не перестає бути ознакою еталонного знання, зокрема й на території України мистецтво риторики, у межах якого аналізується образне порівняння, вивчають саме матинською мовою (підручники 3 риторики мекторів Києво-Могицянської академіi). В англомовному середовищі процес адаптації науки до національної мови почався раніше, водночас термінологічний апарат здебільшого формується матинізованими назвами (принаймні в рамках дослідження образного мовлення), і на кінець 18 століття спостерігається чітка тенденція до використання єдиного терміна - simile - безвідносно до прагматичнозмістового наповнення раніше виокремлених різновидів позначуваного явища. Як результат, створилася макуна, яка потребує пояснення еквівалентності раніше 
використовуваних і сьогодні вживаних термінів, зважаючи на первісну різнорідність їнього денотативного наповнення, або визнання дещо звуженого, формалізованого підходу до потрактування образного порівняння в переважній більшості ангмомовної наукової мітератури, про що спорадично зазначено в мовознавчих розвідках. Зокрема, як би це парадоксально не звучало, але "Енциклопедія з риторики" [16: 741], яка містить статтю Simile, указує як термінологічні відповідники грецьке слово parabolē, матинські parabola i similitudo, проте зовсім не згадує давньогрецького icon, на мегендарний Аристотелівський приклад якого принципово покликаються практично всі сучасні дослідники. Виникає питання: якщо класичний приклад icon "He jumped like a lion" ("Він кинувся, як мев") $€$ центральною структурносемантичною матрицею для відбору одиниць аналізу, названих simile, то чому термінологічним еквівалентом вважають parabola, яка в давньогрецькій спеціалізованій мітературі позначала "придумане порівняння", а в епоху Середньовіччя почала пов'язуватися 3 притчами Христа морально-повчального характеру? Очевидно, переклад термінів (так, як це склалося в слов'янських мовах), який відображав би смислове наповнення поняття, був би доречнішим, ніж транслітерація матинського слова. Крім того, усе вказує на те, що не варто створювати буквальну структурно-семантичну кальку як мірило відповідності понять із домінантою змісту над формою.

у дослідженнях 16-18 століть спостерігається поступова віддаленість від середньовічного гоміметичного потрактування образного порівняння на користь повернення до античного наповнення розглядуваної категорії практично-соціальними завданнями. Переважна більшість англомовних науковців того часу традиційно виокремлюють функції образного порівняння, які вже стають стандартними: здатність оживцяти, прикрашати, розважати й демонструвати. Варто зазначити, що ніхто 3 дослідників доби Нового часу (окрім Х. Блера та Ф. Прокоповича) не проводить зіставного аналізу між образним порівнянням і метафорою, обмежуючись описовим переліком тропів і фігур мовлення 3 настільки різним потрактуванням критеріїв ї розмежування, що сама необхідність факту розподілу описуваних явищ на фігури та тропи починає бути сумнівною.

\section{СПИСОК ВИКОРИСТАНИХ ДЖЕРЕА ТА МІТЕРАТУРИ}

1. Аомоносов М. В. 1810. Краткое руководство къ краснорьчію. СанктПетербург: Императорская Академия Наук. 328 с.

2. Прокопович Ф. URL: http://litopys.org.ua/procop/proc109.ht m\#rozd8 (дата звернення: 10.09.2021).

3. Black M. More about metaphor. Metaphor and thought / ed. A. Ortony. Cambridge and New York: Cambridge University Press, 1993. P. 19-41.

4. Blackwall A. Introduction to the classics, with an Essay on rhetoric, and an Appendix exhibiting the most valuable and useful editions of the classical writers. London: Lackington, 1809. 256 p.

5. Blair H. Lectures on rhetoric and belles lettres. Early English Books Online Text Creation Partnership. URL: https://quod.lib.umich.edu/e/ecco/004 786433.0001.001/1:20?rgn=div $1 ; \mathrm{view}=\mathrm{f}$ ulltext (дата звернення: 10.09.2021).

6. Campbell G. The Philosophy of Rhetoric. Carbondale: Southern Illinois University Press, 2008. 423 p.

7. Cox L. 1532. The Art or crafte of Rhetoryke. Release Date: May 26, 2008 [EBook \#25612]. URL: https://www.gutenberg.org/files / 25612 25612-h/25612-h.htm звернення: 10.09.2021).

8. Erasmus R. 1522. Novum Testamentum. URL: https://archive.org/details/roterodamvs 
-erasmus-novum-testamentum-1522

(дата звернення: 10.09.2021).

9. Erasmus, D. d. 1536., Udall, Nicholas, 1505-1556. The first tome or volume of the Paraphrase of Erasmus vpon the Newe Testamente. Early English Books Online Text Creation Partnership. $\quad$ URL: https://quod.lib.umich.edu/e/eebo/A16 036.0001.001/1:5?rgn=div1; view=fulltex t (дата звернення: 10.09.2021).

10. Filonik J. Metaphors in Rhetoric: From Ancient Greek to 21st-Century Politics. S. Papaioannou, A. Serafim and M. Edwards (eds.). Brill's Companion to the Reception of Ancient Rhetoric, 2020. $\mathrm{P}$.

$1-28$.

DOI: $10.13140 / R G .2 .2 .30432 .71682$

11. Gibbons T. Rhetoric; Or, A View of Its Principal Tropes and Figures, in their Origin and Powers: with a Variety of Rules to escape Errors and Blemishes, and Attain Propriety and Elegance in Composition. London: J. and W. Oliver, 1767. 547 p.

12. Kirby, J. T. Aristotle on metaphor. American Journal of Philology 118(4): 1997. P. 517-554.

13. Lakoff G. and Johnson M. Metaphors we live by. Chicago and London: The Universitu of Chicago Press, 1980. 242 p.

14. Lakoff $\mathrm{G}$. The contemporary theory of metaphor. Metaphor and thought / ed. A. Ortony. Cambridge and New York: Cambridge University Press, 1993. P. 202-251.

15. Mahon J. E. Getting your sources right: what Aristotle didn't say." In Researching and applying metaphor. eds. L. Cameron and G. Low. Cambridge and New York: Cambridge University Press, 1999. 69-80.

16. Nate R. Simile. Encyclopedia of Rhetoric / ed. Thomas O. Sloane. (C) 2006 Oxford University Press. Encyclopedia of Rhetoric: (e-reference edition). Oxford University Press. The Midnight University. $2007 . \quad$ URL: http: / /www.oxfordrhetoric.com/entry?entry=t223.e227 (дата звернення: 10.09.2021).
17. Novokhatko A.The linguistic treatment of metaphor in Quintilian. Pallas (103), 2017. P. 311-318.

18. Ortony A. Metaphor, language and thought. Metaphor and thought / ed. A. Ortony. Cambridge and New York: Cambridge University Press, 1999. P. 116.

19. Peacham H. The Garden of Eloquence. London: H. Jackson. 1577. URL:

https:// books.google.com.ua/books?id=1 xYzAQAAMAAJ\&printsec $=$ frontcover\&hl= $\underline{\text { ru\&source }=g b s \_g e \_s u m m a r y \_r \& c a d}=0 \# v$ =onepage\&q=trop\&f=false звернення: 10.09.2021).

20. Puttenham G. The Arte of English Poesie. Release Date: August 3, 2005 [EBook \#16420]. 1589. URL: https://www.gutenberg.org/cache/epub /16420/pg16420.html (дата звернення: 10.09.2021).

21. Ricoeur P. Between Rhetoric and Poetics. Essays on Aristotle's Rhetoric, ed. A. Rorty. Berkeley/Los Angeles/London: University of California Press, 1996. P. 324-84.

22. Ricoeur P. The Metaphorical Process as Cognition, Imagination, and Feeling. Critical Inquiry. vol. 5 (1), 1978. P. 143-159.

23. Sherry R. A Treatise of Schemes and Tropes. Release Date: March 30, 2009 [EBook \#28447]. 1550. URL: https://www.gutenberg.org/files / 28447 /28447-h/28447-h.htm (дата звернення: 10.09.2021).

24. Smith A. Lectures on Rhetoric and Belles Lettres. Vol. 4. Indianapolis: Liberty Fund, 1985. 291 p.

25. Swiggers P. Cognitive aspects of Aristotle's theory of metaphor. // Glotta 62(1/2), 1984. P. 40-45.

26. Wierzbicka A. Metaphors linguists live by: Lakoff \& Johnson contra Aristotle. Research on Language and Social Interaction 19(2), 1986. P. 287313.

27. Wilson T. The Arte of Rhetorique. Oxford: Clarendon Press. 1560. URL: https://quod.lib.umich.edu/cgi/t/text/t 
ext-idx?c=eebo;idno=A15530.0001.001

(дата звернення: 10.09.2021).

\section{REFERENCES (TRANSLATED \& TRANSLITERATED)}

1. Lomonosov M. V. (1810). Kratkoe rukovodstvo k" krasnorbchiyu. [A Short Introduction to Eloquence]: SanktPeterburg: Imperatorskaya Akademiya Nauk. 328 s. [in Russian].

2. Prokopovich F. URL: http://litopys.org.ua/procop/proc109.ht m\#rozd8 (data zvernennja: 10.09.2021) [in Ukrainian].

3. Black M. (1993). More about metaphor. Metaphor and thought / ed. A. Ortony. Cambridge and New York: Cambridge University Press. P. 19-41. [in English].

4. Blackwall A. (1809). Introduction to the classics, with an Essay on rhetoric, and an Appendix exhibiting the most valuable and useful editions of the classical writers. London: Lackington. 256 p. [in English].

5. Blair H. Lectures on rhetoric and belles lettres. Early English Books Online Text Creation Partnership. URL: https://quod.lib.umich.edu/e/ecco/004 786433.0001.001/1:20?rgn=div1; view $=\mathrm{f}$ ulltext (data zvernennia: 10.09.2021). [in English].

6. Campbell G. (2008). The Philosophy of Rhetoric. Carbondale: Southern Illinois University Press. 423 p. [in English].

7. Cox L. 1532. The Art or crafte of Rhetoryke. Release Date: May 26, 2008 [EBook \#25612]. URL: https://www.gutenberg.org/files/25612 25612-h/25612-h.htm zvernennia: 10.09.2021). [in English].

8. Erasmus R. 1522. Novum Testamentum. URL: https://archive.org/details/roterodamvs -erasmus-novum-testamentum-1522 (data zvernennia: 10.09.2021). [in English].

9. Erasmus, D. d. 1536., Udall, Nicholas, 1505-1556. The first tome or volume of the Paraphrase of Erasmus vpon the Newe Testamente. Early English Books Online Text Creation
Partnership.

URL:

https://quod.lib.umich.edu/e/eebo/A16 $036.0001 .001 / 1: 5$ ?rgn=div1; view $=$ fulltex $\underline{t}$ (data zvernennia: 10.09.2021). [in English].

10. Filonik J. (2020). Metaphors in Rhetoric: From Ancient Greek to 21stCentury Politics. S. Papaioannou, A. Serafim and M. Edwards (eds.). Brill's Companion to the Reception of Ancient Rhetoric. P. 1-28. DOI: $10.13140 /$ RG. 2.2.30432.71682 [in English].

11. Gibbons T. (1767). Rhetoric; Or, A View of Its Principal Tropes and Figures, in their Origin and Powers: with a Variety of Rules to escape Errors and Blemishes, and Attain Propriety and Elegance in Composition. London: J. and W. Oliver. 547 p. [in English].

12. Kirby, J. T. (1997). Aristotle on metaphor. American Journal of Philology 118(4). P. 517-554. [in English].

13. Lakoff G. and Johnson M. (1980). Metaphors we live by. Chicago and London: The Universitu of Chicago Press. 242 p. [in English].

14. Lakoff G. (1993). The contemporary theory of metaphor. Metaphor and thought / ed. A. Ortony. Cambridge and New York: Cambridge University Press. P. 202-251. [in English].

15. Mahon J. E. (1999). Getting your sources right: what Aristotle didn't say." In Researching and applying metaphor. eds. L. Cameron and G. Low. Cambridge and New York : Cambridge University Press. 69-80. [in English].

16. Nate R. (2007). Simile. Encyclopedia of Rhetoric / ed. Thomas O. Sloane. (c) 2006 Oxford University Press. Encyclopedia of Rhetoric: (ereference edition). Oxford University Press. The Midnight University. URL: http:/ / www.oxford-

rhetoric.com/entry?entry=t223.e227

(data zvernennia: 10.09.2021). [in English].

17. Novokhatko A. (2017). The linguistic treatment of metaphor in 
Quintilian. Pallas (103). P. 311-318. [in English].

18. Ortony A. (1999). Metaphor, language and thought. Metaphor and thought / ed. A. Ortony. Cambridge and New York: Cambridge University Press. P. 1-16. [in English].

19. Peacham H. The Garden of Eloquence. London: H. Jackson. 1577. URL:

https: / / books.google.com.ua/books?id=1 xYzAQAAMAAJ\&printsec $=$ frontcover\&hl $=$ ru\&source $=$ gbs_ge_summary_r\&cad $=0 \# v$ =onepage \&q=trop\&f=false (data zvernennia: 10.09.2021). [in English].

20. Puttenham G. The Arte of English Poesie. Release Date: August 3, 2005 [EBook \#16420]. $1589 . \quad$ URL: https://www.gutenberg.org/cache/epub /16420/pg16420.html (data zvernennia: 10.09.2021). [in English].

21. Ricoeur P. (1996). Between Rhetoric and Poetics. Essays on Aristotle's Rhetoric, ed. A. Rorty. Berkeley/Los Angeles/London: University of California Press, 1996. P. 324-84. [in English].

22. Ricoeur P. (1978). The Metaphorical Process as Cognition,

Стаття надійшла до редколегії: 21.10.2021

Схвалено до друку: 26.11.2021
Imagination, and Feeling. Critical Inquiry. vol. 5 (1). P. 143-159. [in English].

23. Sherry R. A Treatise of Schemes and Tropes. Release Date: March 30, 2009 [EBook \#28447]. 1550. URL: https://www.gutenberg.org/files/28447 128447-h/28447-h.htm (data zvernennia: 10.09.2021). [in English].

24. Smith A. (1985). Lectures on Rhetoric and Belles Lettres. Vol. 4. Indianapolis: Liberty Fund. 291 p. [in English].

25. Swiggers P. (1984). Cognitive aspects of Aristotle's theory of metaphor. Glotta 62(1/2). P. 40-45. [in English].

26. Wierzbicka A. (1986). Metaphors linguists live by: Lakoff \& Johnson contra Aristotle. Research on Language and Social Interaction 19(2). P. 287-313. [in English].

27. Wilson T. The Arte of Rhetorique. Oxford : Clarendon Press. 1560. URL: https://quod.lib.umich.edu/cgi/t/text/t ext-idx?c=eebo;idno=A15530.0001.001 (data zvernennia: 10.09.2021). [in English]. 